This is the author's Post-print version (final draft post-refereeing as accepted for publication by the journal). The definitive, peer-reviewed and edited version of this article is published as: Niedomysl T., Östh J. and van Ham M. (2010) The Globalisation of Marriage Fields: The Swedish Case. Journal of Ethnic and Migration Studies 36(7), 1119-1138. http://dx.doi.org/10.1080/13691830903488184

\title{
The Globalisation of Marriage Fields: The Swedish Case
}

\section{Thomas Niedomysl, John Östh, Maarten van Ham}

Thomas Niedomysl is Research Fellow at the Institute for Futures Studies, Stockholm. John Östh is Research Fellow in the Dept of Social and Economic Geography, Uppsala University. Maarten van Ham is Lecturer in Geography at the University of St Andrews. Correspondence to Dr T. Niedomysl, Institute for Futures Studies, PO Box 591, 10131 Stockholm, Sweden. E-mail: thomas.niedomysl@ framtidsstudier.se

\begin{abstract}
Marriage fields - the geographical areas where people meet to partner traditionally tend to be relatively small and local. Increasing international travel and the use of internet have broadened the geographical opportunity structure of potential partners. This increases the risk of meeting a partner from abroad, possibly resulting in an increase of international marriage migration. This paper uses unique longitudinal population data for the whole of Sweden to explore the globalisation of Swedish marriage fields. The results show an increase of marriage migrants in Sweden between 1990 and 2004, although absolute numbers remain relatively low. The paper yields two new insights not previously recorded in the literature. The first is that we found a substantial proportion of all marriage migrants in Sweden to be males while most existing literature on marriage migration focuses almost exclusively on females. The second is that the pattern of geographical origins of marriage migrants is highly gendered with male and female marriage migrants in Sweden originating from different regions in the world. The results suggest that different mechanisms underlie male and female marriage migration.
\end{abstract}

Key words: Marriage, Migration, Globalisation, Sweden

\section{Introduction}

Marriage fields - the geographical area where people meet to partner - traditionally tend to be relatively small and local (see for a literature review Houston et al., 2005). Bossard (1932), for example, shows that one third of all couples who got married in a metropolitan region in the U.S. lived within five or less blocks from each other. Similarly, Coleman and Haskey (1986) found that most people who form a couple in the UK initially live reasonably close to each other. In order to find a partner, people need to be able to meet and interact (arranged marriages are an exception). Proximity makes frequency of interaction easier and therefore increases the chances of contact that lead to long term relationships (e.g., Bossard, 1932; 
Kennedy, 1943; Clark, 1952; Coleman \& Haskey, 1986; Lieberson \& Waters, 1988; Kalmijn $\&$ Flap, 2001). The fact that people spend most of their time in small and functional units, like their school, neighbourhood, and workplace (Kalmijn, 1998) and have limited spatial activity spaces (Hägerstrand, 1970) produces the generality that individuals often marry the boy or 'girl next door' (Houston et al., 2005). There is, however, evidence that the range of contexts where people meet is growing and that the local context (the neighbourhood) is loosing importance as a marriage field (Bozon \& Heran, 1989; Kalmijn \& Flap, 2001).

On a national scale, people are increasingly mobile for purposes of work and leisure and modern technology allows us to interact in real time with people in different locations (mobile phones, internet). If you meet a potential partner outside your own local area, communication technology allows us to build up a relationship without regular physical contact. Singles are increasingly making use of partnering websites - covering whole nations - which bring them into contact with potential partners they would otherwise not 'meet' locally. These developments are likely to take the geography out of the initial phases of partnering and broaden marriage fields for at least a part of the population, although it is interesting to note that many partnering websites have the option to search only in your own region.

People are also getting increasingly mobile on an international scale. Increasing ease of air travel for work and leisure, rising numbers of individuals studying, working and travelling abroad, and the emergence of international partnering websites can be expected to increase the 'risk' of meeting a potential partner from abroad (see Piper, 2003). Globalisation could through reshaping the geographic opportunity set of potential partners - lead to a globalisation of marriage fields for at least a part of the population. In addition, processes of modernization make that people are more likely to have a positive attitude to marry with someone from outside their own group (Uunk, 1996; Hendrickx, 1994), and in this 'age of migration' (Castles \& Miller, 1998) moving to another country becomes more common. Together, these developments can be expected to make people more open to the concept of partnering with someone from abroad.

There is an increasing body of literature on international marriages. Some of the literature focuses on the experience of well-educated middle class couples in US and Europe (Johnson \& Warren, 1994; Breger \& Hill, 1998; Schreiber, 1992). An increase in the number of international marriages does not necessarily mean that marriage fields are globalising. It might just indicate that more and more people live outside their country of origin, and still meet locally. Other literature studies immigrants who recruit a partner from their country of origin, which is generally seen as evidence of immigrants not integrating in their 'host' society (González-Ferrer, 2006). This is a form of marriage migration, but not the main focus of this paper. A literature that more explicitly deals with geographically expanding marriage fields is the literature on marriage migration linked to the commercialised marriage mediation industry. This industry has, since the 1960s, increased enormously in size and spread across borders (Kojima, 2001). According to the literature most of these commercially 'arranged' marriages involve women from less developed countries - sometimes referred to as 'mailorder brides' - who are 'recruited' to more developed countries (Piper, 1999; 2003).

There is some evidence that a growing group of people 'recruit' their partner from geographically distant locations (Johnson \& Warren, 1994; Cottrell, 1990), but information on volumes and changes over time are not available, as most studies are qualitative and based on small samples (Cottrell, 1990). Moreover, our knowledge of marriage migration is biased towards examples from the commercial marriage industry, focussing on the experiences of women from less developed countries moving to developed countries. As a result, there is a lack of insight in more general patterns of marriage migration, especially with regard to male marriage migration. In this paper we aim to fill this gap by studying changes in volumes of marriage migration between 1990 and 2004 by country of origin and gender using unique 
longitudinal population data for Sweden (1990-2004). This paper will answer the following two research questions. First, how can we describe the geography of international marriage migration to Sweden and are there any signs of a globalisation of Swedish marriage fields between 1990 and 2004? And second, is there any variation in demographic (age and sex) or socioeconomic (education) characteristics of partners from different countries of origin? In our analyses we focus on couples consisting of one partner native to Sweden who 'recruits' a partner from another country.

There are two reasons why Sweden is a particularly well suited country for this research. The first is that Sweden has unique longitudinal population data of high quality for the whole Swedish population (1990-2004). This data makes it possible to study changes over time in volumes of immigration, by country of origin, and demographic characteristics of the immigrant. The second reason is that Sweden has for some time now been considered to be one of the world's most globalised countries (Dreher, 2006). Swedes are frequent international travellers for both business and leisure and Sweden is very well connected to the internet (Ellegård \& Vilhelmson, 2004). This makes Sweden an interesting country to test our hypothesis on the globalisation of marriage fields. If such an effect exists, it should be visible in Sweden.

\section{Theory and research context}

\subsection{The marriage market}

To understand patterns of partnering behaviour (including geographical patterns), researchers often use the metaphor of the market (Blau, 1977; Kalmijn, 1998). The marriage market consists of a demand side where individual preferences play a role (with regard to love, physical attraction, income and social status, age, ethnicity, religion, etcetera) and a supply side, the opportunity structure of the market. The opportunity structure determines the probability that someone is able to realise his or her preferences. The choice of partner is constrained by the demographic composition of the search area and the type and number of meeting places people frequent (England \& Farkas, 1986; Mare, 1991; Blossfeld \& Meyer 1988; Dagsvik, 2000; Kalmijn \& Flap, 2001). A literature review by Houston and colleagues (2005) shows that the marriage market metaphor is used to study the relative availability of suitable partners at the local (e.g., Ní Bhrolcháin et al., 2002), regional (e.g., Lichter et al,. 1991; Brien, 1997; Farley, 1999; Bratter \& Zuberi, 2001), national (Ní Bhrolcháin, 2001; Qian \& Lichter, 2001; Rosenfeld, 2002), and international scales (e.g., Piper, 1997; Adams \& Ghose, 2003).

There are several things we can learn from the metaphor of the market about the geography of marriage migration. First, the opportunity structure of the marriage market plays an important role in our understanding of the type of partner people choose (Kalmijn, 1998). As we argued in the introduction, this opportunity structure has broadened enormously for (frequent) international travellers and internet users, which we expect to be reflected in marriage patterns. We can expect marriage migrants in Sweden to originate from countries relatively close to Sweden and countries frequently visited by Swedes. Second, according to Becker's (1973) model of marriage migration, marriage markets in different countries are competitive and an individual looking for a partner has to choose between alternative markets. When an individual decides to search outside his or her local market this reflects that the utility of a match in the foreign market is higher than the utility of a match with someone from the local market (Çelikaksoy et al., 2006). We can expect that there is a category of people who deliberately search for a foreign partner because they look for characteristics they 
can not find locally. Whether or not such a partner is found and from which country this partner originates, depend partly on the supply of potential partners.

\subsection{Commercial marriage industry}

The scale of the commercial marriage industry - one of the main channels through which people actively search for a foreign partner - has increased significantly since the 1960s (Ford, 2004). Globalisation is leading to a commercialisation of marriage migration (Lu, 2005). The internet is becoming more and more important as a marriage market, both on the national and the international scale (Lu, 2005). The use of commercial websites is relatively new, but the concept of 'mail-order brides' existed long before internet existed. The availability of services through the internet means that people can explore commercial websites in the privacy of their own home, lowering the threshold to use these services. In our data we have no possibility to research the extent of 'mail order brides' (or 'mail order grooms'), but given much of the recent literature this is a phenomenon that should be given attention.

According to Lu (2005) scholarly attention for mail-order brides started about 14 years ago (del Rosario 1994; Glodava \& Onizuka, 1994; Robinson, 1996). This early work links the mail-order bride phenomenon to sex tourism and sex trafficking (Barry, 1995) and more recent literature studies mail-order brides in the context of female labour migration for domestic work (see Lu, 2005). Most mail-order brides originate from Southeast Asia, South America, and Russia, and the male partners they seek come primarily from the United States or Western Europe (Paez Minervini \& McAndrew, 2006). Lu (2005) warns that one has to be careful not to stigmatise mail-order brides as many women benefit and 'true love' may well play a role. It is also stressed that there is no information available about the volume of crossborder marriages that are commercially arranged since people also meet during, for instance business and leisure travel, and through non-commercial dating websites, which is likely to be far more common than commercially arranged marriages. What is interesting about the term 'mail-order bride' is that the term is almost exclusively used with reference to women from economically less developed countries who partner with men from richer countries (Lu, 2005). When a woman from a western country finds a partner through a commercial site we generally do not speak of a mail-order bride (Lu, 2005).

\subsection{The gendered nature of (marriage) migration}

The mail-order bride literature raises the important question why the focus is almost exclusively on female marriage migrants and not on male marriage migrants. A simple explanation could be that international male marriage migrants are very rare. Surfing international matchmaking sites on the internet shows that most partners 'on offer' are female, and only few men use the internet to 'advertise' themselves internationally to potential partners. Alternatively, the attention for female marriage migrants might be explained by an academic interest in (sexual) exploitation and gendered inequality. As Osipovich (2004) points out, mail-order brides have been portrayed mainly as victims. Issues of exploitation are likely to be of less importance in the case of male marriage migrants.

There is also a gender dimension in the geography or origins and destinations of marriage migrants. Most marriage migrants in the literature are women from relatively poor countries moving to more affluent countries. The main explanation used is one of poverty and exploitation where women in poor countries are 'forced' to 'sell themselves' in exchange for a better life. Johnson (2007), in a study of Russian mail-order brides, offers a much more nuanced explanation. In her research, Western husbands of mail-order brides stated that they were looking for a partner with traditional family values, something they could not find locally. The mail-order brides stated that they were looking for a stable husband willing to 
build up a family, a type husband hard to find in their home country. This research shows that mail-order brides are not necessarily poor women trying to escape unfavourable living circumstances, but also middle-class women not being able to find a suitable partner in their own country (see also Paez Minervini \& McAndrew, 2006).

Alternative explanations of marriage migration see marriage as a means of obtaining a legal residence status in a western country. Geographic patterns of marriage migration might also be reinforced through forms of chain migration and explained by using network theory (see Montgomery, 1991 on networks and labour-market outcomes). In this view, marriage migrants share (positive) experiences with people in their home country which encourages more people (mainly women?) to follow in their footsteps. Another explanation of gendered patterns of marriage migration is risk-sharing behaviour in families in poor countries where especially daughters are encouraged to marry abroad to minimize income risks (Stark, 1991).

\subsection{Positive and negative assortative mating}

Studying the socio-demographic characteristics of marriage migrants and their native Swedish partners may shed some light on the mechanisms underlying marriage migration, especially the gendered nature of marriage migration. In general, people choose a partner from their own group (endogamy) and close in social status (homogamy) (Kalmijn, 1998). The result is that partners are often very similar in terms of age, level of education, ethnic background, religion, and social status (Smits, 1996). Although women are in general slightly younger than their male partner (Buunk et al., 2001; Kenrick et al., 1993). Part of these marriage patterns can be explained by the fact that peoples' choice of partner is constrained by the opportunities available (the supply side argument, see Fisher et al., 1977; Flap, 1999; Huckfeldt, 1983; Marsden, 1990; Kalmijn \& Flap, 2001). Preferences also play an important role: people simply seem to prefer a partner from the same social background (positive assortative mating). Marriage patterns are also connected with the mutual satisfaction of needs - whether concerned with diverse issues such as age, physical attractiveness, economic security, charm or the attainment of a residence permit (Klein, 2001; Górny \& Kepinska, 2004).

According to Çelikaksoy and colleagues (2006), in theory, both negative and positive assortative mating on age and education can occur (see also Becker, 1973). Negative assortative mating would provide evidence for the social exchange hypothesis (Davis, 1941; Merton, 1941; Schoen \& Wooldredge, 1989; Kalmijn, 1998) that partners exchange resources by their marriage to improve social status. People, for example might compensate unfavourable characteristics (being poor) by a more favourable characteristic (physical attractiveness, being young, or having a high educational level). We might find some evidence of negative assortative mating as a consequence of exchange of resources between the relatively wealthy native Swedes and the recruited partner (see also Çelikaksoy et al., 2006).

\subsection{Hypotheses}

The above literature review leads to several 'hypotheses' on international marriage migration. First, we expect to see an increase of marriage migration to Sweden since the early 1990s. As most of the literature focuses on the experiences of women moving abroad, we expect more women than men to move to Sweden to partner with a native Swede. The literature is not very clear on the volume of male marriage migration we can expect to find. With regard to the countries of origin we expect that in general regions nearby and with the least cultural distance (the Nordic countries, Western and Eastern Europe) are likely to be the most important suppliers of partners for both men and women. The literature on mail-order brides also suggests that South-east Asia, Russia and South America are important suppliers of brides. Again, the literature is less clear on the origin of male partners. The social exchange 
theory leads us to expect to find evidence of negative assortative mating: we expect especially female partners from low income regions to be much younger than their native Swedish partners. We also expect female partners from low income regions to be higher educated than their Swedish partners. The literature is less clear about what to expect for male partners from abroad.

\section{Data and research design}

For this project we used a longitudinal micro database of the entire Swedish population drawn from a number of different administrative registers (Statistics Sweden, 2005). From an international perspective, the database is unique as it consists of linked annual demographic, geographic and socioeconomic data for each individual living in Sweden, for the whole 1990 to 2004 period.

In this paper we focus on couples consisting of a native Swede and a foreign partner. We are only interested in those partnerships where the first contact is likely to have been made before the foreign partner moved to Sweden. Hence, we are not interested in couples which were formed while both partners lived in Sweden. Because of the nature of the data we have to assume that if people enter the country in a given year and have formed a partnership by the end of the year that they have entered the country to form a relationship. We define Swedish natives as people born in Sweden whose parents were also born in Sweden. This excludes second generation immigrants who recruit a partner from the homeland of their parents. We define couples as either cohabiting or being married. Because cohabitation is not formally registered we had to assume that a male and a female living in the same residential location form a cohabiting couple. We excluded same sex couples from our analyses.

During the years $1990-2004$, a total of 485,473 people migrated to Sweden, on a population of around 9 million. Of those who entered Sweden, 9 per cent (43,862 individuals) married or cohabitated with a Swede within one year of arrival and this is the population we extracted from the database. Of this group, again 9 per cent shared the same country of origin as the non-native Swede (3,694 individuals). This left us with a population of 40,168 couples consisting of a native Swede and a foreign partner, formed within a year after the foreign partner entered Sweden. We summarized the countries of origin into nine world regions, using definitions from Statistics Sweden. In addition, we also used a country classification from the World Bank (2007) in which countries are divided into low-, middle- and high income countries according to their gross national income, which is thought to be indicative of their economic level of development.

\subsection{Note on ethics}

The nature of our project and the type of data we use raise some questions about research ethics. Since much of the literature on international marriage migration has portrayed stories of abuse and human tragedies there is the risk of stigmatising individuals from certain countries of origin. It is therefore important to stress that the data we used in this project do not tell us anything about people's motivations to migrate, their feelings for their new partner, or whether they moved out of free will or not. Using our data we can only show facts like the number of immigrants, their countries of origin and their characteristics.

The results of our study should therefore be interpreted in light of other relevant literature, being careful not to produce or reproduce any stigma based on prejudice or anecdotic evidence and myths. We also have to be careful with the fact that what may be considered normal or abnormal or right or wrong in one country or region, might be perceived different in another country or even another region within the same country. For example, a 
relationship between a young woman from a developing country and a much older man from a developed country might be prejudiced as a case of exploitation. But the same situation might be beneficial for both partners, simply out of love, or perhaps to provide the woman with status in her home country and provide her with the opportunity to escape living circumstances she found to be undesirable.

\section{Results}

\subsection{Volume and region of origin}

Figure 1 shows how the volume of immigration to Sweden has developed since 1990. The scale on the left hand side refers to the total number of immigrants and the scale on the right hand side to the number of marriage immigrants. The total number of immigrants shows a 17 per cent increase between 1990 and 2004 (from 32,753 in 1990 to 38,376 in 2004). The peak of immigrants in 1993 is related to the war in former Yugoslavia. The number of immigrants who moved to Sweden and married or cohabited with a native Swede increased with 37 per cent (from 2,519 in 1990 to 3,449 in 2004). For the general Swedish population both the rate of marriage unions and the share of single households have remained at the same levels during this time period (Statistics Sweden, 2007a and 2007b). The relatively strong increase in the number of marriage immigrants compared to the total number of immigrants gives some evidence for the globalisation of marriage fields hypothesis, although the absolute number of marriage migrants per year remains low.

(Figure 1 about here)

When we break down the number of marriage immigrants by gender we see that the number of men who moved to Sweden and married a Swedish woman has increased from 1,136 in 1990 to 1,455 by 2004 , an increase of 28 per cent. The number of women who moved to Sweden to marry a Swedish man has increased from 1,383 in 1990 to 1,994 in 2004, which is an increase of 44 per cent. In 199045 per cent of all marriage immigrants were male and in 2004 this had dropped slightly to 42 per cent. This is a fairly equal gender balance compared to, for example, Japan where according to Piper (2003), 75 per cent of all international marriages involve Asian women and Japanese men or Poland where 68 per cent of all international marriages involve foreign women (Górny \& Kepinska, 2004). Given the emphasis on female marriage migrants in the literature it is surprising to find relatively large numbers of male marriage migrants in Sweden. It has been suggested that some of these marriages involving men might be arranged marriages to help these men to get a legal residence status in Sweden.

Figure 2 shows a series of 3 maps with the geographic origin of immigrants over the 1990-2004 period. Map A shows the origin of all immigrants. The largest group of immigrants come from Eastern Europe \& Russia ( 25 per cent), the second largest group from North Africa \& the Middle East (22 per cent) the third largest group from the other Nordic countries (18 per cent) and the fourth place is shared by Southeast \& other Asia and Western Europe (both 10 per cent).

(Figure 2 about here)

Map B and C show the geographic distribution of marriage immigrants by gender. Map B shows that 24 per cent of all immigrant men who migrate to Sweden to partner with a native Swede originate from Western Europe, 19 per cent originate from North Africa \& Middle 
East, 12 per cent from the Nordic countries and 11 per cent from both North America and Eastern Europe \& Russia. For immigrant women who migrate to Sweden to partner with a native Swede the picture looks very different. A total of 29 per cent of these women originate from Southeast \& other Asia, 26 per cent from Eastern Europe \& Russia, 11 per cent from the other Nordic countries, 10 per cent from Southern America and 9 per cent from Western Europe. Figure 2 shows that the geographic pattern of marriage migration is highly gendered, with male and female marriage migrants originating from different world regions.

The last column on the right hand side in Table 1 gives an alternative view on the gendered geography of marriage migration by showing the percentage of immigrants by region and gender of all marriage immigrants. More than 16 per cent of all marriage immigrants to Sweden are women from Southeast \& other Asia, 15 per cent are women from Eastern Europe \& Russia, and 10 per cent are men from Western Europe. The table further shows that since 1990, twice as many men than women came from Western Europe; three times as many women than men from Eastern Europe \& Russia; more than six times as many men than women from Northern Africa \& the Middle East; and more than eight times as many women than men from Southeast \& other Asia.

To shed more light on the gendered geography of marriage migration, Table 1 takes a more dynamic approach by investigating trends in marriage migration over time (1990-2004) by country of origin and gender. We calculated an index figure with a base of a 100 in 1990 for each region by gender. The results show that the fastest growing group of marriage migrants to Sweden are women from Northern Africa \& the Middle East (100 to 293), although it has to be kept in mind that absolute numbers remain small (see column with totals). The next fastest growing group are women from Southeast \& other Asia (100 to 240); then women from South America (100 to 238); then men from South America (100 to 172); men from Africa (100 to 161); and men from Northern Africa \& the Middle East (100 to 158). Table 1 also shows that some regions deliver fairly constant numbers of marriage immigrants per year between 1990 and 2004, for example, North America for both men and women and Western Europe and Eastern Europe \& Russia for women. For ease of presentation we had to present our data summarised in fairly large regions instead of individual countries. Within these regions there may be considerable differences between countries. For example, Alm Stenflo (2001) has shown that during the 1970s and 1980s the level of immigration to Sweden of Polish women who married Swedish men was much higher than currently is the case (see also Cretser, 1999). Immigrants from Russia and the Baltic states are a relatively new phenomenon in Sweden (since the fall of the 'Iron curtain') and compensate for the now much lower volumes of Polish women.

Two overall conclusions can be drawn from the above. The first is that given the emphasis on female marriage migrants in the literature, surprisingly many male marriage migrants come to Sweden. The second is that the geography of marriage migration is highly gendered. Male and female marriage migrants in Sweden originate from different parts of the world. The two largest suppliers of male marriage migrants are Western Europe and Northern Africa \& Middle East while the largest suppliers of female marriage migrants are Southeast \& other Asia and Eastern Europe \& Russia. Between 1990 and 2004, the fastest growing suppliers of both male and female marriage migrants are Northern Africa \& Middle East, the rest of Africa and South America. In the above section, we have restricted ourselves to describing patterns found in the data. In the conclusion and discussion we will work towards an explanation of the gendered geography of marriage migration.

(Table 1 about here) 


\subsection{Age differences between partners}

The mail-order bride literature suggests that there is a category of men who deliberately search for a foreign partner because they have a preference for certain partner characteristics (a young and attractive female with traditional family values) which are difficult to satisfy on the local marriage market. In this section we focus specifically on age. We know that in the general population within a relationship women are on average slightly younger than their male partner. The mail-order bride literature suggests that female marriage migrants from low income countries are on average much younger than their male partner.

Figure 3 consists of two sets of population pyramids showing age structures of marriage migrants and their Swedish partner by gender and type of country (low, middle, and high income countries, using a definition developed by the World Bank). For comparison we have added a population pyramid for Swedish-Swedish couples (pyramid at the bottom of Figure 3 ), showing no notable age differences between partners. The three pyramids for Swedish women and their foreign partner show only small age differences: native women are generally younger than their male foreign partner. The three pyramids showing the age composition of Swedish men and their foreign partner show a much more diverse picture. Swedish men are on average 11 years older than their partner from a low income country, 9.6 years older than their partner from a middle income country, and 2.7 years older than their partner from a high income country.

Table 2 shows the average age difference in years between partners by region of origin of the marriage immigrant. Again, there are no large age differences between native Swedish women and their foreign partner, but striking age differences between Swedish men and their foreign partner. Men are on average respectively 13, 11.2 and 9.5 years older than their partner from Mid \& Northern Africa, Southeast \& other Asia, and Eastern Europe \& Russia. The findings with respect to age differences between partners are in line with what we expected based on the mail-order bride literature. The fact that there are hardly any age differences between Swedish women and their foreign partner and Swedish men and partners from Western countries might help us to understand some of the mechanisms behind the gendered geography of marriage migration.

\section{(Table 2 about here)}

\subsection{Educational differences between partners}

In this section we zoom in on differences in level of education between the native Swede and the foreign partner. We know from the literature that in the general population within a relationship men on average have a higher level of education than their partner. We also know that increasingly, couples are formed between partners of equal educational level. Table 3 shows the level of education of the imported partner by gender and region of origin. The table uses the same low, middle, and high income categories of countries as before. The results are surprising in that both male and female marriage immigrants from low income countries have on average a higher level of education than marriage immigrants from high income countries. 63 per cent of women from low income countries marrying a native Swedish man have a postsecondary education compared to only 42 per cent of the women originating from a high income country. This finding supports the idea that migrant women from poor countries might be relatively high educated women not being able to find a suitable partner in their own country (Paez Minervini \& McAndrew, 2006).

(Table 3 about here) 
Table 4 further explores the educational level of marriage immigrants by geographic region of origin. A relatively high percentage of women from Northern Africa \& Middle East and from Southeast \& other Asia have a low level of education (only compulsory school). A high percentage of women from Eastern Europe \& Russia, North America, South America and Australia \& Pacific have a high level of education (post-secondary or higher). For male marriage immigrants the picture is very similar with the exception of partners originating from Eastern Europe. A high percentage of men from Eastern Europe have a low level of education and a low percentage have a high level of education. The results from Table 3 and 4 show that, on average, marriage immigrants have relatively high levels of education (see also Górny and Kepinska, 2004), especially women from low income countries.

\section{(Table 4 about here)}

Table 5 explores the distance in educational level between partners by gender and region of origin. According to the homogamy hypothesis we can expect to find that partners have fairly similar levels of education. However, Table 5 shows a more complex and to some extent a more surprising picture. The results show that in the majority of couples with a partner from a high income country, both partners have an equal level of education (60 and 53 per cent) or the imported partner has a higher level of education (30 and 34 per cent). For couples with a partner from a middle income country the picture is more diverse. Also here the equally educated couples are a large group (38 and 36 per cent) but in 39 per cent of these couples the imported partner has the highest level of education (for both men and women). Almost the same picture emerges for those couples with a partner from a low income country. Our results seem to give evidence for the homogamy hypothesis for partners from high income countries and evidence for the negative assortive mating hypothesis - derived from the social exchange theory - for partners from middle and low income countries.

(Table 5 about here)

\section{Conclusion and discussion}

This paper set out to explore the globalisation of Swedish marriage fields. The central idea was that increasing international travel and the use of internet have broadened the geographical opportunity structure of potential partners for Swedish residents, increasing the risk of meeting a potential partner from abroad. We therefore expected to see an increase in marriage migration to Sweden over the last decade and a half. The unique feature of this paper was that we have used longitudinal registration data for the whole Swedish population enabling us to explore changes over time in the volume and geography of marriage migration for a whole country where most previous studies have used qualitative methods. The results show that although the increase of international migration to Sweden has been relatively modest during the years 1990-2004 (an increase by 17 per cent), the numbers of international marriage migrants have increased substantially (by 37 per cent). However, given the relatively small numbers of marriage migrants (2,519 in 1990 up to 3,449 in 2004) it is debatable whether we found enough evidence to make claims about a 'globalisation of Swedish marriage fields'.

This paper has yielded two major new insights in patterns of international marriage migration not previously recorded in the literature. The first is that we found a substantial proportion of all marriage migrants in Sweden to be males. This was surprising as the marriage migration literature is strongly biased towards female marriage migration and the 
experiences of mail-order brides in particular. Our results show that there is a large gap in our knowledge of marriage migration as we know very little about the mechanisms behind male marriage migration. The second major insight arising from our empirical work is that the pattern of geographical origins of marriage migrants is highly gendered. Male and female marriage migrants in Sweden originate from different regions of the world. We also observed large gender differences in patterns of change in volumes of marriage migrants by region of origin between 1990 and 2004. These findings underpin the argument that more work has to be done on male marriage migration as explanations of female marriage migration are unlikely to be valid for males.

The overrepresentation of female marriage migrants in our data from Southeast \& other Asia, Eastern Europe \& Russia, and South America fits in literature on mail-order brides. Also the age and educational differences between partners from these regions and the native Swedish men fits in this literature. The patterns found are likely to reflect both the supply side and the demand side of the marriage market. The supply side consists of females (not males) from traditional mail-order bride regions who advertise themselves as potential partners on commercial matchmaking websites. Some of the couples might also have met in the country of origin of the foreign partner, for example in Thailand, which is a popular holiday destination for Swedes. This might explain the existence of (small numbers of) male marriage migrants from the traditional mail-order bride regions. The demand side for partners from the mail-order bride regions consists of western men with a preference for relatively young females with traditional family values. These men can not find a local match as Swedish women (and western women in general) are on average looking for modern male partners of roughly the same age.

Our research is the first which was able to quantify the age differences between marriage migrants and their native Western partners on the scale of a whole country. Our results have shown that female marriage migrants are on average much younger than their Swedish male partner. Our analyses also show that there is a strong relationship between the income level of a country and age differences between the female marriage migrant and the Swedish male. The largest age differences can be found in couples with partners from the poorest countries. These findings raise important questions about the potential exploitation of the lack of choice for some women by Western men. Also the fact that marriage immigrants from even the poorest countries often have an equal or a higher level of education suggests that many marriage migrants use marriage as a means to escape their home country. The relatively high level of education of marriage migrants, especially those from the lowest income countries, suggest that marriage migration from low income countries also causes some degree of 'brain drain'.

Male marriage migrants are overrepresented among those originating from Western Europe, Africa \& Middle East, Northern America and Australia. Couples with an imported male partner from Western and high income countries show very similar characteristics compared to Swedish-Swedish couples. This suggests that these couples have formed in very similar ways and that the match between partners might have been made during employment or leisure related travel. Some of these couples might have met in Sweden while the foreign male was on a business trip. The male bias in marriage migrants originating from Mid \& South Africa and Northern Africa \& Middle East is intriguing. The pattern found does not fit in existing explanations of marriage migration. The pattern might be linked to preferences for African men for a specific category of Swedish women or, as has been suggested, to arranged marriages linked to obtaining legal residence permits.

Our findings show that that the traditional distance decay of interaction on local marriage markets is less valid for contemporary international marriage migration to Sweden. For example, only 20 per cent of the immigrant women who moved to Sweden to partner with 
a native Swedish man came from the Nordic countries and Western Europe, compared to 29 per cent of immigrant women coming from Southeast and Other Asia. The complex gendered geographical pattern of marriage migration suggests that some forms of marriage migration are conceptually closely linked to other forms of migration. Therefore, explanations of the geography of marriage migration have to be found in combining literatures on mail-order brides, international migration, and job and leisure related travel. Research on marriage migration should move beyond studying mail-order brides and flows of marriage migrants from poor to wealthy countries. More qualitative work is needed on the background and motives of especially male marriage migrants.

\section{References}

Adams, P. and Ghose, R. (2003) 'India.com: the construction of a space between', Progress in Human Geography 27: 414-437.

Alm Stenflo, G. (2001) 'Kärlek över gränserna [Love across borders]', Välfärdsbulletinen 3: 12-13.

Barry, K. (1995) The Prostitution of Sexuality: The Global Exploitation of Women. London: New York University Press.

Becker, G.S. (1973) 'A Theory of Marriage: Part I', The Journal of Political Economy 81(4): 813-846.

Blau, P. (1977) Inequality and heterogeneity: a primitive theory of social structure. New York: Free Press.

Blossfeld, H.P. and Meyer, U. (1988) 'Labor Market Segmentation in the Federal Republic of Germany: An Empirical Study of Segmentation Theories from a Life Course Perspective', European Sociological Review 4: 123-140.

Bossard, J.H.S. (1932) 'Residential propinquity as a factor in marriage selection', The American Journal of Sociology 38(2): 219-24.

Bozon, M. and Heran, F. (1989) 'Finding a spouse: a survey of how French couples meet', Population: An English Selection 44(1): 91-121.

Bratter, J. and Zuberi, T. (2001) 'The demography of difference: shifting trends of racial diversity and interracial marriage 1960-1990', Race and Society 4: 133-148.

Breger, R. and Hill, R. (eds) (1998) Cross-Cultural Marriage - Identity and Choice. Berg: Oxford.

Brien, M. (1997) 'Racial differences in marriage and the role of marriage markets', Journal of Human Resources 32: 741-778.

Buunk, B.P., Dijkstra, P., Kenrick, D.T. and Warntjes, A. (2001) 'Age preferences for mates as related to gender, own age, and involvement level', Evolution and Human Behavior, 22: $241-250$.

Castles, S. and Miller, M. J. (1998) The age of migration. New York, Macmillan.

Çelikaksoy, A., Skyt Nielsen, H. and Verner, M. (2006) Marriage migration: just another case of positive assortative matching? Review of Economics of the Household 4(3): 253-275.

Clark, A. (1952) 'An examination of the operation of residential propinquity as a factor in mate selection', American Sociological Review 17: 17-22.

Coleman, D.A. and Haskey, J.C. (1986) 'Marital Distance and its Geographical Orientation in England and Wales, 1979', Transactions of the Institute of British Geographers 11(3): 337-355.

Cottrell, A.B. (1990) 'Cross-national marriages: a review of the literature', Journal of Comparative Family Studies 21(2): 151-169. 
Cretser, G.A. (1999) 'Cross-national marriage in Sweden: immigration and assimilation 19711993', Journal of Comparative Family Studies 30: 363-380.

Dagsvik, J.K. (2000) 'Aggregation in Matching Markets', International Economic Review, 41:27-57.

Davis, K. (1941) 'Intermarriage in Caste Societies', American Anthropologist 43(3): 376-395.

Del Rosario, V.O. (1994) Lifting the Smoke Screen: Dynamics of Mail-order Brides: Migration from the Philippines. Ph.D. dissertation, Institute of Social Studies, The Hague.

Dreher, A. (2006) 'Does globalization affect growth? Evidence from a new index of globalization', Applied Economics 38(10): 1091-1110.

Ellegård, K, and Vilhelmson, B. (2004) 'Home as a pocket of local order: everyday activities and the friction of distance', Geografiska Annaler 86B: 281-296.

England, P. and Farkas, G. (1986) Households, Employment and Gender: A Social, Economic and Demographic View. New York: Aldine Publications.

Farley, R. (1999) 'Racial issues: recent trends in residential patterns and intermarriage', in Smelser, N. and Alexander, J. (eds) Diversity and its discontents, Princeton, NJ: Princeton University Press, 85-128.

Fischer, C.S., Jackson, R.M., Stueve C.A., Gerson K., McCallister Jones L. and Baldassare M. (1977) Networks and Places: Social Relations in the Urban Setting. Free Press.

Flap, H. (1999) 'Creation and returns to social capital: a new research program', La Revue Tocqueville 20: 1-22.

Ford, E. (2004) The internet bride: A Visual Study of Commercialised Marriage Mediation Within the Colombian Context. Companion Text for Graduation Film MA in Visual Anthropology, Granada Centre for Visual Anthropology.

Glodava, M., and Onizuka, R. (1994) Mail-order brides: Women for sale. Fort Collins, CO: Alaken.

González-Ferrer, A. (2006) 'Who do immigrants marry? Partner choice among single immigrants in Germany', European Sociological Review 22(2): 171-185.

Górny, A. and Kepinska, E. (2004) Mixed marriages from the Ukraine to Poland. Journal of Ethnic and Migration Studies 30(2): 353-372.

Hägerstrand, T. (1970) 'What about people in regional science? ', Papers of the Regional Science Association 24: 7-21.

Hendrickx, J. (1994) The Analysis of Religious Assortative Marriage. University of Nijmegen.

Houston, S., Wright, R., Ellis, M. Holloway, S. and Hudson, M. (2005) 'Places of possibility: where mixed-race partners meet', Progress in Human Geography 29(6): 700-717.

Huckfeldt, R.R. (1983) 'Social contexts, social networks, and urban neighbourhoods: environmental constraints on friendship choice', American Journal of Sociology 89: 651669.

Johnson, E. (2007) Dreaming of a mail-order husband: Russian-american internet romance. Duke University Press.

Johnson, W, Warren M (eds.) (1994) Inside the Mixed Marriage. University Press of America: Lanham.

Kalmijn, M. (1998) 'Intermarriage and homogamy: causes, patterns, trends', Annual Review of Sociology 24(1): 395-421.

Kalmijn, M. and Flap, H. (2001) 'Assortative meeting and mating: unintended consequences of organized settings for partner choices', Social Forces 79: 1289-312.

Kennedy, R. (1943) 'Premarital residential propinquity and ethnic endogamy', American Journal of Sociology 48: 580-84. 
Kenrick, D.T., Groth, G.E., Trost, M.R. and Sadalla, E.K. (1993) 'Integrating evolutionary and social exchange perspectives on relationships: Effects of gender, self-appraisal,and involvement on mate selection', Journal of Personality and Social Psychology, 64: 951969.

Klein, T. (2001) 'Intermarriages between Germans and foreigners in Germany', Journal of Comparative Family Studies 32(3): 325-346.

Kojima,Y. (2001) 'In the business of cultural reproduction: Theoretical implications of the mail-order bride phenomenon', Women's Studies International Forum, 24: 199-209.

Lichter, D., LeClere, F. and McLaughlin, D. (1991) 'Local marriage markets and the marital behavior of black-and-white women', American Journal of Sociology 96: 843-67.

Lieberson, S. and Waters, M. (1988) From many strands: ethnic and racial groups in contemporary America. New York: Russell Sage.

Lu, M.C.W. (2005) 'Commercially Arranged Marriage Migration: Case Studies of Crossborder Marriages in Taiwan', Indian Journal of Gender Studies 12(2-3): 275-303.

Mare, D. (1991) 'Five Decades of Educational Assortative Mating', American Sociological Review 56: 15-32.

Marsden, P. (1990) 'Network Diversity, Substructures, and opportunities for Contact', in Calhoun C., Meyer M.W. and Scott W.R. (eds) Structures of Power and Constraint. Cambridge University Press: 397-410.

Merton, R. (1941) 'Intermarriage and the social structure: fact and theory', Psychiatry 4: 361374.

Montgomery, J. D. (1991) 'Social networks and labor-market outcomes: Toward an economic analysis', The American Economic Review 81(5): 1408-1418.

Ní Bhrolcháin, M. (2001) 'Flexibility in the marriage market', Population 55: 899-939.

Ní Bhrolcháin, M., Wilson, T. and Sigle-Rushton, W. (2002) 'Local marriage markets in Great Britain; how diverse? ', Population Trends 109: 27-35.

Nielsen, H. S., Rosholm, M., Smith, N. and L. Husted (2003) Intergenerational Transmission and the School-to-Work Transition for $2^{\text {nd }}$ generation immigrants. Working Paper. Aarhus School of Business.

Osipovich, T. (2004) 'Russian mail-order brides in us public discourse: Sex, crime, and cultural stereotypes', in Stulhofer A and Sandfort, T. (eds) Sexuality and Gender in Postcommunist Eastern Europe and Russia, Binghamton, NY: Haworth Press, 321-242.

Paez Minervini, B. and McAndrew, F.T. (2006) 'The Mating Strategies and Mate Preferences of Mail Order Brides', Cross-Cultural Research, 40(2): 111-129.

Piper, N. (1997) 'International marriage in Japan: 'race' and 'gender' perspectives', Gender, Place and Culture 4: 321-38.

Piper, N. (1999) 'Labour Migration, Trafficking and International Marriage: Female CrossBorder Movements into Japan', Asian Journal of Women's Studies, 5(2): 69-99.

Piper, N. (2003) 'Wife of worker? Worker or wife? Marriage and cross-border migration in contemporary Japan', International Journal of Population Geography 9(6): 457-469.

Qian, Z. and Lichter, D. (2001) 'Measuring marital assimilation: intermarriage among natives and immigrants', Social Science Research 30: 289-312.

Robinson, K. (1996) 'Of Mail-order Brides and 'Boys' Own' Tales: Representations of AsianAustralian Marriage', Feminist Review, 52: 53-68.

Rosenfeld, M. (2002) 'Measures of assimilation in the marriage market: Mexican Americans 1970-1990', Journal of Marriage and Family 64: 152-162.

Schoen, R. and Wooldredge, J. (1989) 'Marriage choices in North Carolina and Virginia, 1969-71 and 1979-81'. Journal of Marriage and the Family 51: 465-481.

Schreiber, P.M. (1992). Binationale Ehen [international marriages]. Deutscher Studienverlag: Weinheim. 
Smits, J. (1996) Trouwpatronen en Sociale Openheid [Marriage Patterns and Social Openness]. PhD Thesis, Katholieke Universiteit Nijmegen, The Netherlands.

Stark, O. (1991) The migration of labor. Cambridge, MA, USA: Blackwell.

Statistics Sweden (2005) En longitudinell databas kring utbildning, inkomst och sysselsättning (LOUISE) 1990-2002. Bakgrundsfakta, Arbetsmarknads- och utbildningsstatistik.

Statistics Sweden (2007a) Undersökningar av levnadsförhållanden (ULF). Available via www.scb.se.

Statistics Sweden (2007b) Befolkningsutveckling; födda, döda, in- och utvandring, gifta, skilda 1949-2006, Tidsserier. Available via www.scb.se.

Uunk, W. (1996) Who marries whom? The role of social origin, education and high culture in mate selection of industrial societies during the twentieth century. University of Nijmegen.

World Bank (2007) Country classification according to level of economic development. Available via www.worldbank.org (accessed 2007-06-26). 
Figure 1. Total number of immigrants and marriage immigrants moving to Sweden, 19902004.

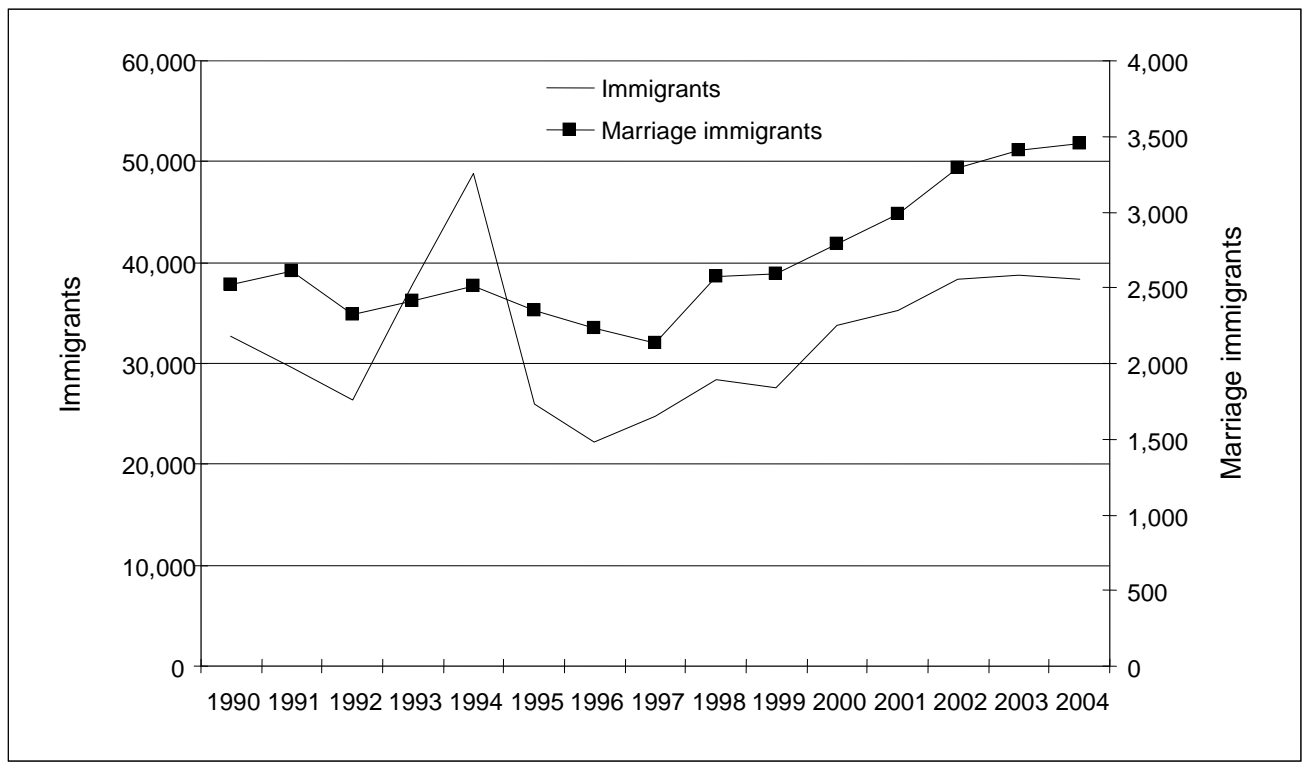




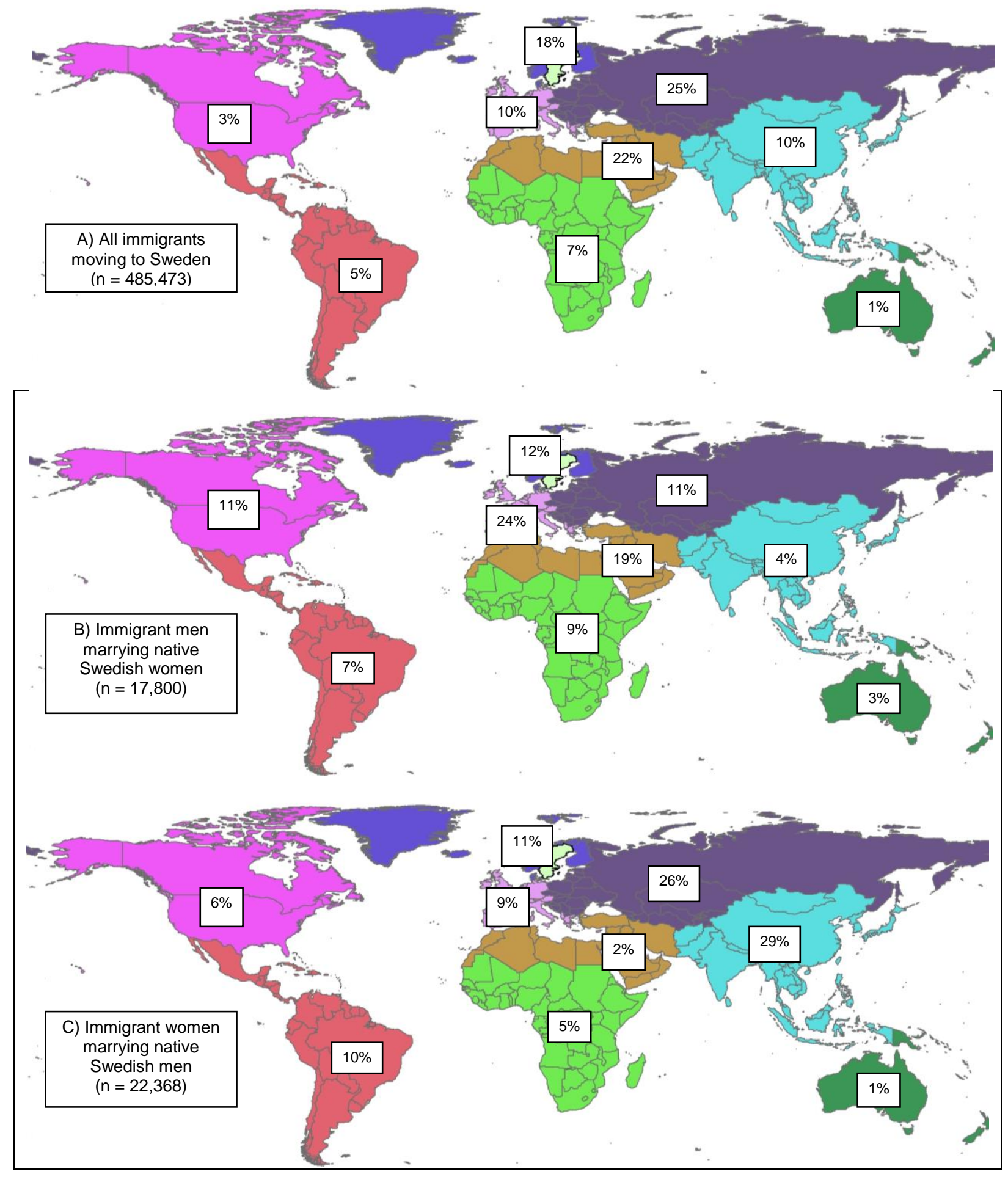

Figure 2. Regions of origin of A) All immigrants to Sweden; B) Immigrant men marrying native Swedish women; C) Immigrant women marrying native Swedish men. Totals volumes for 1990-2004. 


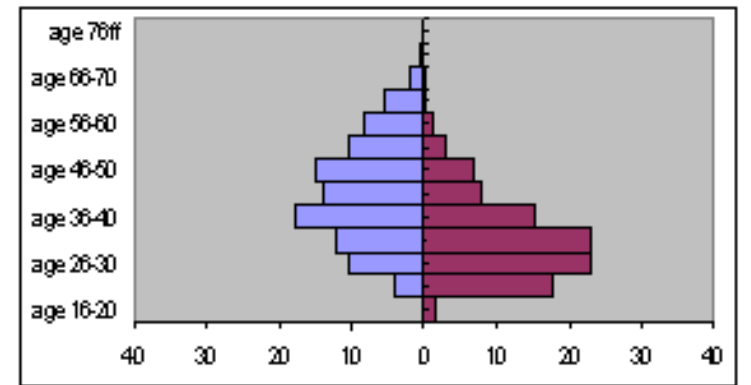

Swedish men (left) marrying women from low income country (right) (mean age diff 11.0 years, median diff 9 years).

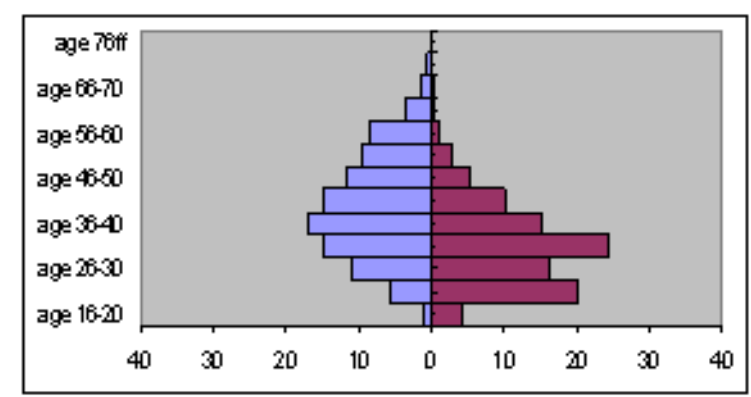

Swedish men (left) marrying women from middle income country (right) (mean age diff 9.6 years, median diff 8 years).

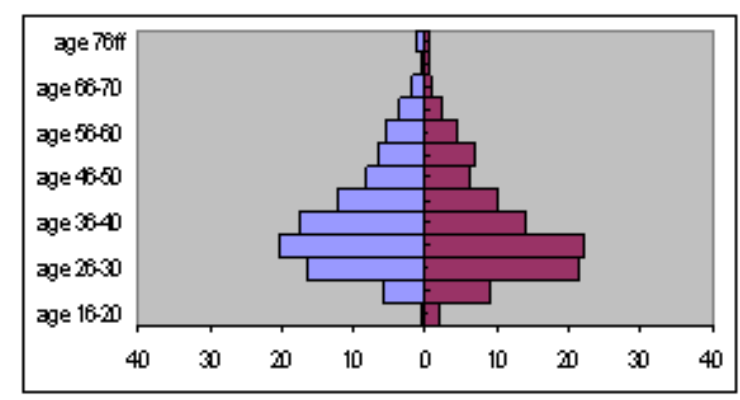

Swedish men (left) marrying women from high income country (right) (mean age diff 2.7 years, median diff 2 years).

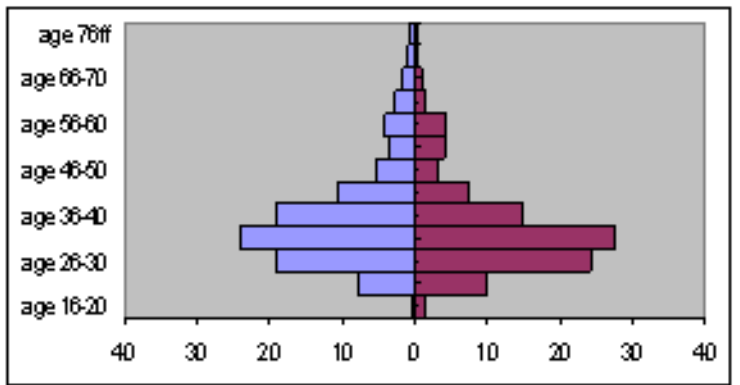

Swedish women (right) marrying men from low income country (left) (mean age diff -1.4 years, median diff 0 years).

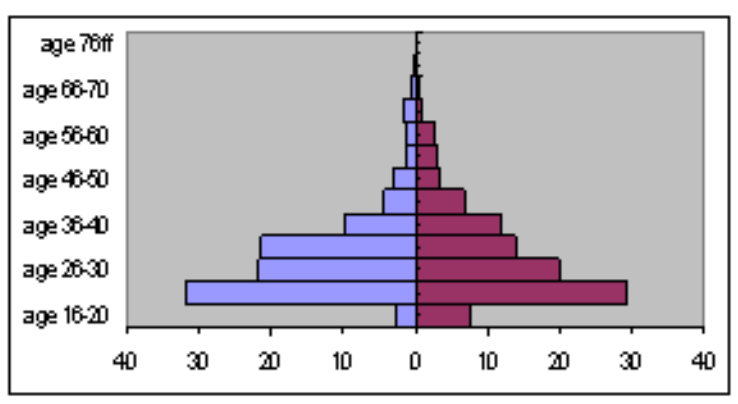

Swedish women (right) marrying men from middle income country (left) (mean age diff 2.1 years, median diff 2 years).

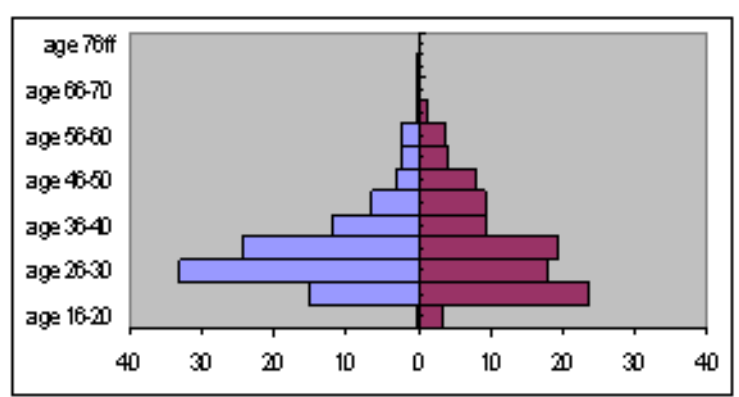

Swedish women (right) marrying men from high income country (left) (mean age diff -1.7 years, median diff 0 years).

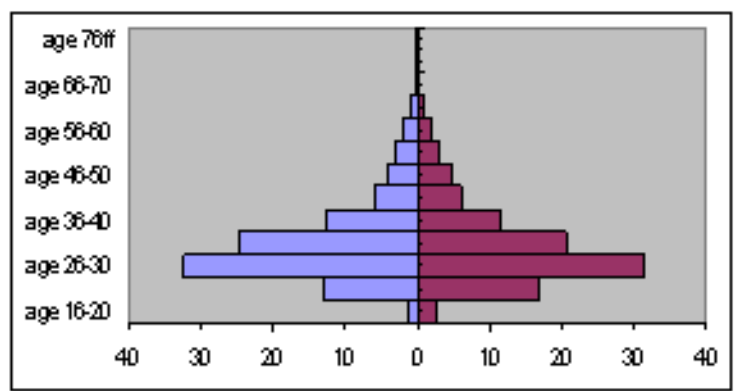

Swedish men (left) marrying Swedish women (right) (mean age diff 0 years, median diff 1 year).

Figure 3. Population pyramids showing age structures of immigrants who marry or partner with a native Swede, 2004. 
Table 1. Annual number of marriage immigrants by region and gender $1990-2004$, index figures $(1990=100 \%)$ and totals

\begin{tabular}{|c|c|c|c|c|c|c|c|c|c|c|c|c|c|c|c|c|c|c|}
\hline & & 1990 & 1991 & 1992 & 1993 & 1994 & 1995 & 1996 & 1997 & 1998 & 1999 & 2000 & 2001 & 2002 & 2003 & 2004 & Total $\mathbf{n}$ & $\begin{array}{c}\% \text { overall } \\
\text { total }\end{array}$ \\
\hline \multirow[t]{2}{*}{ Nordic countries } & Women & 100 & 73 & 77 & 68 & 67 & 68 & 62 & 62 & 82 & 84 & 85 & 101 & 90 & 84 & 76 & 2,506 & 6.2 \\
\hline & Men & 100 & 91 & 82 & 92 & 92 & 99 & 117 & 92 & 127 & 128 & 151 & 177 & 179 & 158 & 142 & 2,171 & 5.4 \\
\hline \multirow[t]{2}{*}{ Western Europe } & Women & 100 & 89 & 76 & 99 & 83 & 90 & 84 & 70 & 94 & 89 & 99 & 97 & 84 & 95 & 109 & 2,021 & 5.0 \\
\hline & Men & 100 & 82 & 70 & 76 & 76 & 104 & 97 & 81 & 97 & 84 & 117 & 111 & 111 & 105 & 134 & 4,234 & 10.5 \\
\hline \multirow[t]{2}{*}{ Eastern Europe/Russia } & Women & 100 & 103 & 100 & 95 & 101 & 82 & 70 & 72 & 81 & 92 & 92 & 91 & 110 & 96 & 103 & 5,922 & 14.7 \\
\hline & Men & 100 & 145 & 96 & 175 & 213 & 137 & 103 & 125 & 103 & 64 & 71 & 88 & 75 & 101 & 82 & 1,978 & 4.9 \\
\hline \multirow[t]{2}{*}{ Mid-/South Africa } & Women & 100 & 112 & 93 & 84 & 116 & 93 & 111 & 102 & 182 & 128 & 107 & 125 & 151 & 135 & 142 & 1,015 & 2.5 \\
\hline & Men & 100 & 137 & 129 & 133 & 149 & 170 & 122 & 124 & 120 & 132 & 109 & 95 & 137 & 144 & 161 & 1,607 & 4.0 \\
\hline \multirow[t]{2}{*}{ North Africa/Middle East } & Women & 100 & 264 & 207 & 243 & 171 & 193 & 193 & 136 & 229 & 364 & 250 & 343 & 400 & 421 & 293 & 533 & 1.3 \\
\hline & Men & 100 & 152 & 116 & 102 & 106 & 62 & 69 & 71 & 92 & 93 & 86 & 105 & 108 & 150 & 158 & 3,389 & 8.4 \\
\hline \multirow[t]{2}{*}{ South-East/Other Asia } & Women & 100 & 111 & 97 & 111 & 99 & 93 & 84 & 86 & 115 & 132 & 155 & 164 & 217 & 254 & 240 & 6,547 & 16.3 \\
\hline & Men & 100 & 94 & 64 & 84 & 91 & 89 & 86 & 81 & 91 & 91 & 58 & 61 & 80 & 84 & 66 & 780 & 1.9 \\
\hline \multirow[t]{2}{*}{ North America } & Women & 100 & 76 & 84 & 73 & 75 & 71 & 93 & 80 & 97 & 86 & 125 & 116 & 142 & 112 & 111 & 1,326 & 3.3 \\
\hline & Men & 100 & 68 & 87 & 65 & 87 & 94 & 86 & 84 & 79 & 95 & 91 & 111 & 116 & 104 & 99 & 1,927 & 4.8 \\
\hline \multirow[t]{2}{*}{ South America } & Women & 100 & 132 & 126 & 103 & 132 & 124 & 149 & 133 & 164 & 154 & 186 & 193 & 207 & 204 & 238 & 2,252 & 5.6 \\
\hline & Men & 100 & 122 & 78 & 105 & 97 & 131 & 131 & 123 & 131 & 142 & 134 & 180 & 152 & 161 & 172 & 1,254 & 3.1 \\
\hline \multirow[t]{2}{*}{ Australia/Pacific } & Women & 100 & 112 & 82 & 88 & 65 & 76 & 71 & 94 & 100 & 88 & 94 & 94 & 153 & 129 & 100 & 246 & 0.6 \\
\hline & Men & 100 & 49 & 69 & 54 & 59 & 44 & 69 & 49 & 95 & 95 & 100 & 92 & 92 & 131 & 74 & 457 & 1.1 \\
\hline \multirow[t]{3}{*}{ World } & Women & 100 & 101 & 95 & 95 & 95 & 87 & 83 & 81 & 103 & 108 & 117 & 123 & 143 & 144 & 144 & 22,368 & 55.7 \\
\hline & Men & 100 & 107 & 89 & 97 & 106 & 101 & 95 & 90 & 101 & 97 & 103 & 113 & 116 & 124 & 128 & 17,800 & 44.3 \\
\hline & Total & 2,519 & 2,611 & 2,319 & 2,412 & 2,510 & 2,351 & 2,231 & 2,132 & 2,572 & 2,588 & 2,792 & 2,985 & 3,292 & 3,405 & 3,449 & 40,168 & 100 \\
\hline
\end{tabular}


Table 2. Age differences per region between immigrant men and women marrying a Swede, 2004

\begin{tabular}{lcccccc}
\hline & \multicolumn{2}{c}{$\begin{array}{c}\text { Swedish men marrying women } \\
\text { from: }\end{array}$} & & \multicolumn{2}{c}{$\begin{array}{c}\text { Swedish woman marrying men } \\
\text { from: }\end{array}$} \\
\cline { 2 - 3 } \cline { 5 - 6 } & $\begin{array}{c}\text { Mean age } \\
\text { diff. in years }\end{array}$ & $\begin{array}{c}\text { Median age } \\
\text { diff. in years }\end{array}$ & & $\begin{array}{c}\text { Mean age } \\
\text { diff. in years }\end{array}$ & $\begin{array}{c}\text { Median age } \\
\text { diff. in years }\end{array}$ \\
\hline Sweden & 0.0 & 1 & & 0.0 & 1 \\
Nordic countries & 2.7 & 2 & & 2.1 & 2 \\
Western Europe & 3.8 & 3 & & 1.9 & 2 \\
Eastern Europe & 9.5 & 8 & & -0.4 & -1 \\
Mid-/NorthAfrica & 13.0 & 11 & & -2.4 & 0 \\
North Africa/Middle East & 4.6 & 4 & & -2.0 & 3 \\
South-East/Other Asia & 11.2 & 10 & & -0.1 & 0 \\
North America & 1.2 & 1 & & 2.8 & 2 \\
South America & 6.7 & 4 & & -0.3 & 1 \\
Australia/ Pacific & 0.0 & 1 & & 1.4 & 0 \\
\hline
\end{tabular}

Table 3. Level of education of immigrant men and women marrying a Swede by development state of the region of origin, 2004

\begin{tabular}{|c|c|c|c|c|}
\hline \multicolumn{5}{|c|}{ Swedish men marrying immigrant women with } \\
\hline & Compulsary school & Upper secondary school & Post-secondary, & \\
\hline $\begin{array}{l}\text { Low income country } \\
\text { Middle income country } \\
\text { High income country }\end{array}$ & $\begin{array}{l}14 \% \\
26 \% \\
15 \%\end{array}$ & $\begin{array}{l}23 \% \\
18 \% \\
43 \%\end{array}$ & $\begin{array}{l}63 \% \\
56 \% \\
42 \%\end{array}$ & $\begin{array}{l}100 \% \\
100 \% \\
100 \%\end{array}$ \\
\hline \multicolumn{5}{|c|}{ Swedish woman marrying immigrant man with } \\
\hline $\begin{array}{l}\text { Low income country } \\
\text { Middle income country } \\
\text { High income country }\end{array}$ & $\begin{array}{l}16 \% \\
22 \% \\
15 \%\end{array}$ & $\begin{array}{l}33 \% \\
31 \% \\
44 \%\end{array}$ & $\begin{array}{l}51 \% \\
47 \% \\
41 \%\end{array}$ & $\begin{array}{l}100 \% \\
100 \% \\
100 \%\end{array}$ \\
\hline
\end{tabular}

Table 4. Level of education of immigrant men and women marrying a Swede by region of origin, 2004 Swedish men marrying immigrant women with Compulsary school Upper secondary school Post-secondary, tertiary

\begin{tabular}{lrlll}
\hline & & & & \\
Nordic countries & $8 \%$ & $41 \%$ & $51 \%$ & $100 \%$ \\
Western Europe & $13 \%$ & $39 \%$ & $48 \%$ & $100 \%$ \\
Eastern Europe \& Russia & $11 \%$ & $27 \%$ & $62 \%$ & $100 \%$ \\
Mid \& South Africa & $20 \%$ & $39 \%$ & $41 \%$ & $100 \%$ \\
Northern Africa \& Middle East & $26 \%$ & $51 \%$ & $23 \%$ & $100 \%$ \\
Southeast \& other Asia & $36 \%$ & $18 \%$ & $46 \%$ & $100 \%$ \\
North America & $5 \%$ & $30 \%$ & $65 \%$ & $100 \%$ \\
South America & $8 \%$ & $36 \%$ & $56 \%$ & $100 \%$ \\
Australia \& Pacific & $2 \%$ & $41 \%$ & $57 \%$ & $100 \%$
\end{tabular}

Swedish woman marrying immigrant man with

Compulsary school Upper secondary school Post-secondary, tertiary

\begin{tabular}{|c|c|c|c|c|}
\hline Nordic countries & $11 \%$ & $37 \%$ & $43 \%$ & $101 \%$ \\
\hline Western Europe & $10 \%$ & $32 \%$ & $59 \%$ & $101 \%$ \\
\hline Eastern Europe \& Russia & $20 \%$ & $45 \%$ & $35 \%$ & $100 \%$ \\
\hline Mid \& South Africa & $14 \%$ & $40 \%$ & $46 \%$ & $100 \%$ \\
\hline Northern Africa \& Middle East & $24 \%$ & $35 \%$ & $41 \%$ & $100 \%$ \\
\hline Southeast \& other Asia & $20 \%$ & $54 \%$ & $27 \%$ & $101 \%$ \\
\hline North America & $4 \%$ & $31 \%$ & $65 \%$ & $100 \%$ \\
\hline South America & $11 \%$ & $43 \%$ & $46 \%$ & $100 \%$ \\
\hline Australia \& Pacific & $8 \%$ & $32 \%$ & $61 \%$ & $101 \%$ \\
\hline
\end{tabular}


Table 5. Educational distances between partners, 2004

\begin{tabular}{lccc}
\hline & \multicolumn{2}{c}{ Percentage of } & Swedish men marrying immigrant women \\
\cline { 2 - 4 } & Low-income country & Middle-income country & High-income country \\
\hline Immigrant much more educated & 11 & 9 & 5 \\
Immigrant more educated & 25 & 30 & 25 \\
Equally educated & 40 & 38 & 60 \\
Swede more educated & 20 & 20 & 9 \\
Swede much more educated & 4 & 4 & 1 \\
\hline & \multicolumn{1}{c}{ Percentage of } & Swedish women marrying immigrant men \\
\hline Immigrant much more educated & Low-income country & Middle-income country & High-income country \\
\cline { 2 - 4 } Immigrant more educated & 8 & 9 & 5 \\
Equally educated & 28 & 30 & 29 \\
Swede more educated & 40 & 36 & 53 \\
Swede much more educated & 17 & 21 & 11 \\
\hline
\end{tabular}

